\title{
Analysis of Students' Misconception on General Biology Concepts Using Four-Tier Diagnostic Test (FTDT)
}

\author{
Trio Ageng Prayitno ${ }^{*}{ }^{*}$ Nuril Hidayati ${ }^{2}$ \\ 1,2IKIP Budi Utomo, Malang, Indonesia
}

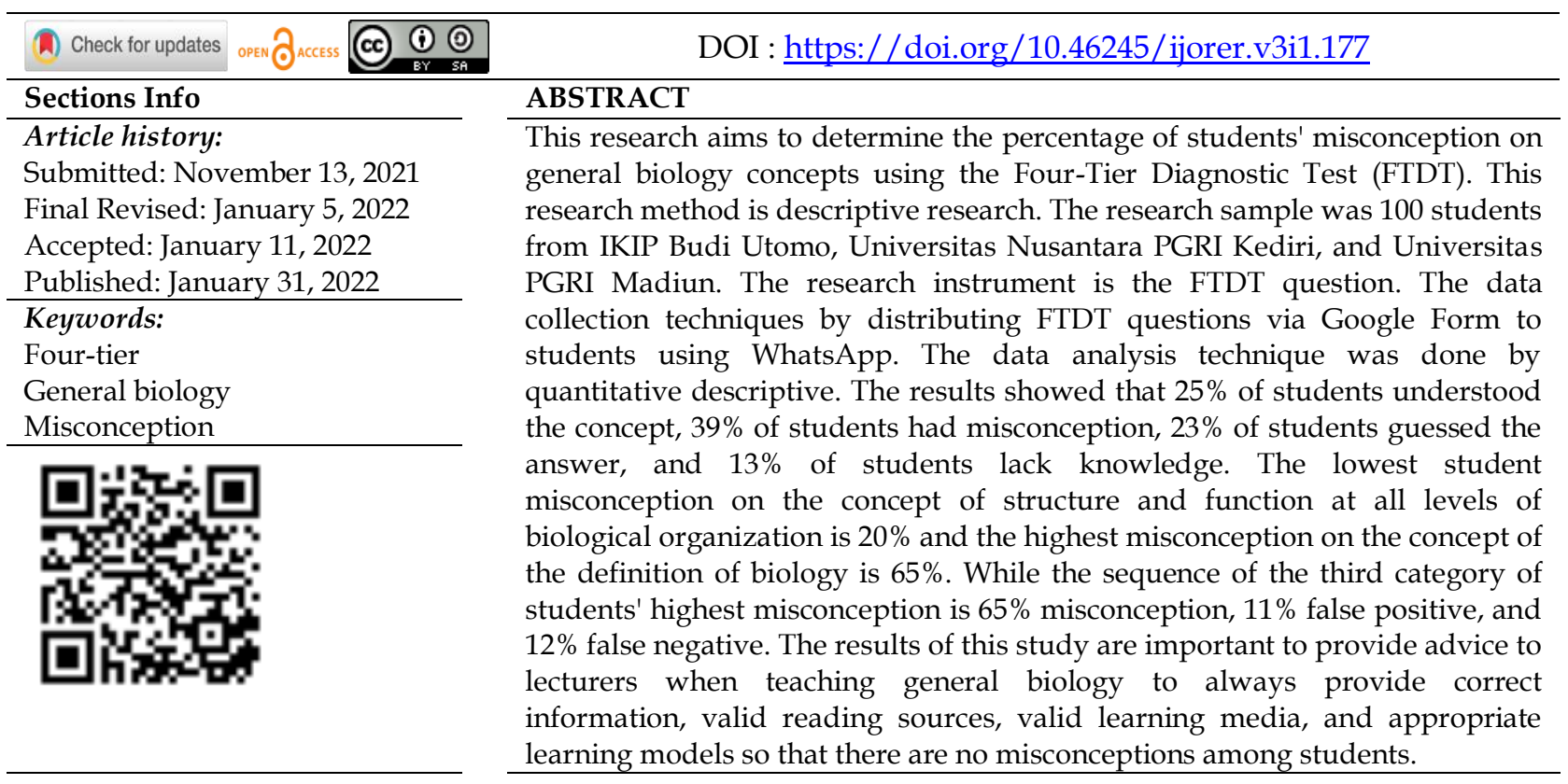

\section{INTRODUCTION}

Prospective biology educators or teachers must master general biology concepts well for teaching provision in Junior High School and Senior High School levels as a form of their professional competence. General biology is a basic and prerequisite course that must be mastered by students of the Department of Biology Education (Kurikulum, 2017). General biology includes concepts that will be studied again in-depth in courses in the next semester (Ita, 2020). For example, the theory of the cell is the basic unit for the structure and function of organisms which will be deepened again in the cell biology course. So that students must have the correct general biological concepts as the basis for the scientific footing that they will master. General biology is one of the subjects that has a fairly high level of difficulty for students in mastering the concept (Çimer, 2012; Etobro \& Fabinu, 2017; Fauzi \& Fariantika, 2018).

The success rate of students in mastering general biology concepts is still in the poor category in Higher Education. The difficulties experienced by students can be caused by several factors including the learning strategies brought by the teacher, student habits in learning, low learning intensity, students' fear of certain topics, and the lack of learning resources (Muspikawijay et al., 2017; Etobro \& Fabinu, 2017; Ichsan \& Mulyani, 2018). Students who have difficulty understanding and interpreting concepts will interpret the concepts they are learning on their own, causing misconceptions in themselves (Savira et al., 2019; Kamilah \& Suwarna, 2019). Misconceptions can occur because of the acceptance of wrong information, integration errors, and perceptions that are not the same as scientific principles (Kumandaş et al., 2018; Duda et al., 2020; 
Wahyono \& Susetyorini, 2021). Misconceptions can cause delays in the transfer of new information related to the concepts to be learned by students (Rukmana, 2017).

Misconceptions can be formed from a discrepancy between the knowledge possessed by students and the theory being studied (Verkade et al., 2017; Widarti et al., 2017). When students are studying a theory in class, they have different prejudices from the theory they are studying because of mistakes in past experiences (Muliyani, 2018; Duda et al., 2020). General biology learning activities that are carried out online also influence the formation of misconceptions (Rajhans et al., 2020). Concepts in general biology learn a lot about theories that are abstract and have a relatively high level of difficulty causing misconceptions in students (Halim et al., 2014; Üce \& Ceyhan, 2019).

Several previous researchs discussed the impact of learning carried out during a pandemic with misconceptions (Rajhans et al., 2020), research on misconceptions is more about the relationship between misconceptions and learning (Halim et al., 2014; Widarti et al., 2017; Wahyono \& Susetyorini, 2021) and identification of misconceptions to determine the number of misconceptions (Ang \& Shahrill, 2014; Bekkink et al, 2016; (Budiarto et al, 2020). However, there are no studies that measure misconceptions as a follow-up effort to reduce or overcome these misconceptions. This research aims to analyze misconceptions in general biology courses using the Four-Tier Diagnostic Test (FTDT) questions in Higher Education. This research is important to be carried out as a basis for the preparation of appropriate learning media to overcome the problem of misconceptions in general biology courses. FTDT questions can correct concepts correctly and are the result of the development of a three-tier multiple choice consisting of four levels, namely the first level in the form of multiple-choice questions, the second level in the form of confidence in answering questions at the first level, the third level of reasons for choosing the first level answers, and the fourth level. confidence in choosing the answer at the third level (Gurel et al., 2015; Laliyo et al., 2021; Syarafina et al., 2020). Thus, this research aims to determine the percentage of students' misconceptions on general biology concepts by using the Four-Tier Diagnostic Test (FTDT).

\section{RESEARCH METHOD \\ General Background}

The research method used is descriptive research which aims to describe the level of misconceptions in general biological concepts of a research populationThis research phase begins with developing an instrument in the form of eight FTDT questions with each question consisting of four levels. The FTDT questions have been validated by experts and declared valid for use in research. FTDT questions are given to students who have taken general biology courses at several campuses in East Java. Furthermore, the research data were analyzed descriptively quantitatively in the form of percentages.

\section{Participants}

The research sample used was 100 students of the Department of Biology Education who had taken general biology courses at three private campuses, including IKIP Budi Utomo, Universitas PGRI Madiun, dan Universitas Nusantara PGRI Kediri.

\section{Instrument and Procedures}

The research instrument is the FTDT question which is developed from general biological concepts including definition of biology, levels (hierarchy) of biological organization, the interaction of organisms as living things with the environment, 
structure and function at all levels of biological organization, the cell is the basic unit for the structure and function of organisms, the sustainability of life is based on dna as heritable information, biological systems controlled by feedback mechanisms, and evolution as the cause of the unity and diversity of life. These eight FTDT questions have been declared valid after analyzing the student's answer data using the validity and reliability formulas and then integrated with the google form and distributed to research samples using WhatsApp media. The flowchart of research prosedur can be seen in Figure 1.

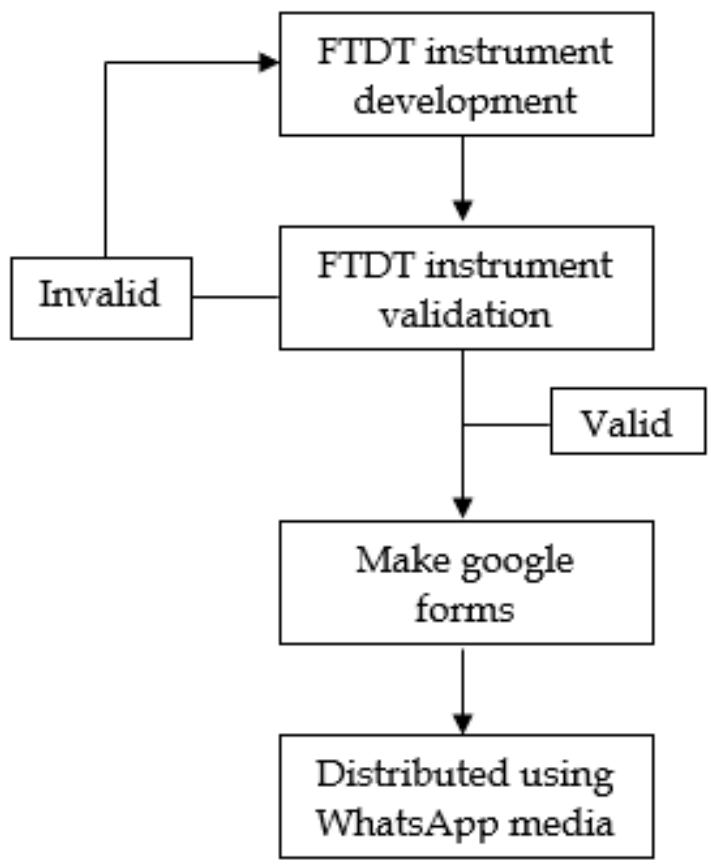

Figure 1. The flowchart of research prosedur.

\section{Data Analysis}

Data analysis was carried out by collecting answers to the given FTDT questions. The answers that have been obtained will be corrected in stages and the results will be categorized according to the criteria for misconceptions. Criteria for misconceptions with FTDT can be seen in Table 1 below. Each question will calculate the percentage of students who understand the concept, misconceptions, false-positive misconceptions, false-negative misconceptions, and lack of knowledge. Furthermore, the percentage results were analyzed descriptively.

Table 1. Criteria for misconceptions with FTDT.

\begin{tabular}{cccccc}
\hline No & Answer & $\begin{array}{c}\text { Confidence } \\
\text { Level }\end{array}$ & Reason & $\begin{array}{c}\text { Confidence } \\
\text { Level }\end{array}$ & Decision \\
\hline 1 & True & Sure & True & Sure & Understand the concept \\
2 & True & Sure & True & Not sure & Lack of knowledge \\
3 & True & Not sure & True & Sure & Lack of knowledge \\
4 & True & Not sure & True & Not sure & Lack of knowledge \\
5 & True & Sure & Wrong & Sure & False-positive misconception \\
6 & True & Sure & Wrong & Not sure & Lack of knowledge \\
7 & True & Not sure & Wrong & Sure & Lack of knowledge \\
8 & True & Not sure & Wrong & Sure & Lack of knowledge \\
9 & Wrong & Sure & True & Sure & False-negative misconception \\
10 & Wrong & Sure & True & Not sure & Lack of knowledge \\
& & & & & \\
\hline
\end{tabular}


Analysis of Students' Misconception on General Biology Concepts Using Four-Tier Diagnostic Test (FTDT)

\begin{tabular}{cccccc}
\hline No & Answer & $\begin{array}{c}\text { Confidence } \\
\text { Level }\end{array}$ & Reason & $\begin{array}{c}\text { Confidence } \\
\text { Level }\end{array}$ & Decision \\
\hline 11 & Wrong & Not sure & True & Sure & Lack of knowledge \\
12 & Wrong & Not sure & True & Not sure & Lack of knowledge \\
13 & Wrong & Sure & Wrong & Sure & Misconception \\
14 & Wrong & Sure & Wrong & Not sure & Lack of knowledge \\
15 & Wrong & Not sure & Wrong & Sure & Lack of knowledge \\
16 & Wrong & Not sure & Wrong & Not sure & Lack of knowledge \\
\hline & & & & & (Gurel et al., 2015)
\end{tabular}

\section{RESULTS AND DISCUSSION}

The results of the research on the analysis of student misconception on general biology concepts can be seen in Table 2 .

Table 2. Percentage of students' misconception on general biology concepts.

\begin{tabular}{|c|c|c|c|c|c|c|}
\hline No & $\begin{array}{l}\text { General biology } \\
\text { concepts }\end{array}$ & $\begin{array}{l}\text { Understan } \\
\text { d the } \\
\text { concept }\end{array}$ & $\begin{array}{l}\text { Misconcep } \\
\text { tion }\end{array}$ & $\begin{array}{l}\text { Misconcep } \\
\text { tion-False } \\
\text { positive }\end{array}$ & $\begin{array}{l}\text { Misconcepti } \\
\text { on-False } \\
\text { negative }\end{array}$ & $\begin{array}{c}\text { Misconcep } \\
\text { tion-lack } \\
\text { of } \\
\text { knowledg } \\
\text { e }\end{array}$ \\
\hline 1 & $\begin{array}{l}\text { Definition of } \\
\text { Biology }\end{array}$ & $9 \%$ & $65 \%$ & $11 \%$ & $12 \%$ & $3 \%$ \\
\hline 2 & $\begin{array}{l}\text { Levels (hierarchy) } \\
\text { of biological } \\
\text { organization }\end{array}$ & $29 \%$ & $44 \%$ & $5 \%$ & $16 \%$ & $6 \%$ \\
\hline 3 & $\begin{array}{l}\text { The interaction of } \\
\text { organisms as } \\
\text { living things with } \\
\text { the environment }\end{array}$ & $16 \%$ & $39 \%$ & $9 \%$ & $23 \%$ & $13 \%$ \\
\hline 4 & $\begin{array}{l}\text { Structure and } \\
\text { function at all } \\
\text { levels of } \\
\text { biological } \\
\text { organization }\end{array}$ & $57 \%$ & $20 \%$ & $11 \%$ & $6 \%$ & $6 \%$ \\
\hline 5 & $\begin{array}{l}\text { The cell is the } \\
\text { basic unit for the } \\
\text { structure and } \\
\text { function of } \\
\text { organisms }\end{array}$ & $36 \%$ & $22 \%$ & $6 \%$ & $17 \%$ & $19 \%$ \\
\hline 6 & $\begin{array}{l}\text { The sustainability } \\
\text { of life is based on } \\
\text { DNA as heritable } \\
\text { information }\end{array}$ & $11 \%$ & $34 \%$ & $30 \%$ & $7 \%$ & $18 \%$ \\
\hline 7 & $\begin{array}{l}\text { Biological systems } \\
\text { controlled by } \\
\text { feedback } \\
\text { mechanisms }\end{array}$ & $2 \%$ & $62 \%$ & $1 \%$ & $10 \%$ & $25 \%$ \\
\hline 8 & $\begin{array}{l}\text { Evolution as the } \\
\text { cause of the unity } \\
\text { and diversity of } \\
\text { life }\end{array}$ & $43 \%$ & $27 \%$ & $13 \%$ & $7 \%$ & $10 \%$ \\
\hline & Mean & $25 \%$ & $39 \%$ & $11 \%$ & $12 \%$ & $13 \%$ \\
\hline
\end{tabular}



(FTDT)

Table 2 shows that $25 \%$ of students understand the concept, $39 \%$ of students experience misconceptions, $11 \%$ of students guess with positive guesses, $12 \%$ of students guess with negative guesses, and $13 \%$ of students lack knowledge of general biology concepts. On average, students who understand general biology concepts are smaller than other students who experience misconceptions and lack knowledge of general biology concepts. Many factors cause students to experience misconceptions about general biology concepts such as past learning experiences, information from textbooks, information from teachers, information from peers, information from the internet, and information obtained from other sources. The above statement is in line with the research results Duda et al. (2020) and Soeharto et al. (2019) that the misconceptions experienced by students in science concepts are caused by various factors such as self-experience, someone in the learning environment, and the references he used.

Student misconceptions occur because of student experiences in everyday life, reading sources that students use, and information from teachers or tutors and friends when students study (Firdaus et al., 2021; Syamsiar \& Raharjo, 2021; Bekkink et al., 2016). Experiences in everyday life will be made the perspective of students' thinking in understanding a concept and often language differences cause students to experience misconceptions when learning (Jauhariyah et al., 2018). Learning resources that are difficult to understand because they are complex and abstract cause students to experience misconceptions (Halim et al., 2018). The teacher's error in explaining the concept to students or the teacher's ignorance of the concept conveyed to students is also the cause of misconceptions in students (Istiyani et al., 2018; Tahya \& Kayadoe, 2020; Widarti et al., 2017). Peers who directly provide information without confirmation and follow-up about the concepts being studied can cause students to experience misconceptions (Duda et al., 2020).

The highest misconception is experienced by students in the concept of the definition of biology. Students tend to be passive and accept directly the meaning of the word biology which comes from the words bios and logos. The students' mindset seems to be constrained by the two words that make up the word biology. Students should have a broader view when defining biology. Biology is a science that studies life. Students should think more broadly about life. When studying life, our eyes must be fixed on objects that exist in life on earth that are not abstract. Objects are biotic and abiotic. Biotics are living things, while abiotics are not living things, but their role is always to support living things in carrying out life. So, the right definition of biology is one of the sciences that study life with biotic, abiotic objects and the interactions between them (Simon et al., 2013; Palennari et al., 2016).

The second misconception experienced by students is on the concept of biological systems controlled by feedback mechanisms. Students seem focused on the textbook they are using and they do not open their minds more broadly to study more about the concept. Actually, this concept looks easy because it can be exemplified by events that students know every day. When we are hungry, our hunger will stimulate our nervous system, sensory system, and movement system to eat. After a sufficient amount of food enters our digestive system, we will stop eating. If we are forced to continue to eat what happens we will remove the food from our bodies through nausea and vomiting. If our muscle cells produce more ATP than what is normally needed, will our muscle cells continue to produce ATP so that our body does not lack energy? So precisely, muscle 
Analysis of Students' Misconception on General Biology Concepts Using Four-Tier Diagnostic Test (FTDT)

cells will not produce ATP anymore because the need for ATP in the body has been fulfilled (Simon et al., 2013; Belk \& Maier, 2013).

The third misconception is on the concept of levels (hierarchy) of biological organization. Students seem constrained by what they have memorized while studying in the past. It is also possible that the teacher or tutor when explaining this concept is not detailed, in-depth, and clear so that students can experience misconceptions. We learn about the levels (hierarchy) of biological organization, then we focus our thoughts on the concrete discussion first, and then we slowly move to the abstract discussion. The levels of biological organization studied in biology start from the biosphere, ecosystems, communities, populations, organisms, organs, tissues, cells, organelles, macromolecules (compounds), molecules, and atoms. If students have understood from concrete to abstract, then we can also test them by understanding from abstract to concrete. By explaining to students that the levels of biological organization studied in biology are atoms, molecules, compounds, organelles, cells, tissues, organs, organ systems, organisms, populations, communities, ecosystems, and the biosphere (Simon et al., 2013; Raven et al., 2017).

The fourth misconception experienced by students is the concept of the interaction of organisms as living things with the environment. Students find it difficult to relate one theory to another in one discussion. They seem to get little information from the reading sources used. When students get the question, "What things will happen if living things interact with their environment?", they seem confused to decipher complex answers to answer the question. Students should think about what components can interact in one place. They have to think about what processes occur when components interact with each other. Furthermore, what products can be used for the needs of these components?. If students can have a systematic and broad mindset, students can answer, when interacting between organisms and their environment, there is a nutrient cycle from soil-producer-consumer-microorganism-soil, energy cycle from light energy-producer-consumer-environment, and changes energy such as chemical energy into energy of motion \& heat energy (Raven et al., 2017; Simon et al., 2013; Belk \& Maier, 2013).

The fifth student's misconception on the sustainability of life is based on DNA as heritable information. Students get inaccurate information from the references used and the number of terms that are not familiar to students. Students must understand the theory gradually correctly to be able to connect between theories with one another so as to reduce the occurrence of misconceptions. When students study DNA as information that is passed on to offspring, students must learn the structure of DNA with its constituent components. Students must learn the mechanism of protein synthesis that involves DNA as a raw material so that students will understand that each link in DNA contains nucleotides (bonds between phosphates, sugars, and one type of nitrogenous base) then the specific nitrogenous bases of DNA in the form of triplets will be translated through the mechanism of protein synthesis (Simon et al., 2013; Gunstream, 2012; Raven et al., 2017).

The sixth misconception experienced by students on the concept of evolution as the cause of the unity and diversity of life. Students only understand a little about evolution without exploring the mechanism of evolution. Students are fixated on memorizing the theory of natural selection by Darwin and used and disused by Lamarck. Students stuck with the theory that he got from the reference which states that humans came from apes. Students need to understand the theory that today's species originated from 
ancestral species that shared a single lineage and underwent modifications. So students will get the theory that the current species are descended from a succession of ancestral species through the process of "descending by modification" described by natural selection, where species that can pass natural selection will survive and can continue their offspring (Simon et al., 2013; Raven et al., 2017; Belk \& Maier, 2013).

The seventh-order misconception experienced by students is the concept of The cell is the basic unit for the structure and function of organisms. Students find it difficult to understand this theory because they do not get the right visualization from the references they use. Students must know the structure of the organelles that make up the cell first and then students must relate the structure to the function it performs. In the end, students can distinguish between prokaryotic cells and eukaryotic cells. Prokaryotic cells are cells that do not yet have a nuclear membrane so that DNA is not separated from other parts of the cell and these cells do not yet have membraneenclosed organelles. Meanwhile, eukaryotic cells are cells that already have a nuclear membrane so that DNA is separated from other cells and these cells already have membrane-enclosed organelles (Simon et al., 2013; Gunstream, 2012).

The eighth student's misconception on the concept of Structure and function at all levels of biological organization. Students cannot capture information in reading sources correctly because of the lack of references used. This concept is easy to understand because there are many illustrations that students encounter in everyday life. However, students cannot construct knowledge from existing examples. Supposedly, students observe the object carefully and examine the results of observations with the theory being studied. Thus, students will gain the concept that structure is always related to its function (Simon et al., 2013; Belk \& Maier, 2013).

The results of the misconception analysis show that the number of false-positive and false-negative misconceptions is $23 \%$. This means that students only guess the answer without mastering the concept correctly. Misconception lack of knowledge as much as $13 \%$ which means students do not understand the concept at all. These misconceptions and lack of knowledge in students occur because the learning process that takes place is mostly done online. The use of online learning models and methods does not run optimally. The information provided by the teacher cannot be received optimally by students. The learning model used also influences the occurrence of misconceptions (Widodo, 2019). The use of less relevant learning media also affects the success of information transfer to students. The above statement is in line with the research Syamsiar \& Raharjo (2021) that the factors of models and learning methods as well as media affect students' misconceptions. Misconceptions and lack of knowledge are also caused by the inability of students to conclude the information they get to build concepts independently. Students are not able to interpret the information obtained during learning, causing misconceptions (Waluyo et.al., 2019). Students are unable to re-explain the concepts learned and will give unclear responses to a question due to low student confidence in the answers they give (Istiyani et al., 2018).

\section{CONCLUSION}

The level of students' misconceptions on general biology concepts is $25 \%$ understanding concepts, $39 \%$ misconceptions, $11 \%$ false-positive misconceptions, $12 \%$ false-negative misconceptions, and 13\% lack of knowledge. Misconceptions can be experienced by students because of past learning experiences, references, teachers, peers, learning models and methods, and learning media. The results of this study are important to 
Analysis of Students' Misconception on General Biology Concepts Using Four-Tier Diagnostic Test (FTDT)

provide advice to lecturers when teaching general biology to always provide correct information, valid reading sources, valid learning media, and appropriate learning models so that there are no misconceptions among students. Furthermore, the results of this study are the basis for research on the development of general biology concept learning media for students in Higher Education.

\section{ACKNOWLEDGEMENTS}

Acknowledgments are given to the Ministry of Education, Culture, Research, and Technology of the Republic of Indonesia and CV Maliki Edulogi Nusantara as research funders.

\section{REFERENCES}

Ang, L. H., \& Shahrill, M. (2014). Identifying students' specific misconceptions in learning probability. International Journal of Probability and Statistics, 3(2), 23-29. https://doi.org/10.5923/j.ijps.20140302.01

Bekkink, M. O., Donders, A. R. T. R., Kooloos, J. G., De Waal, R. M. W., \& Ruiter, D. J. (2016). Uncovering students' misconceptions by assessment of their written questions. BMC (Medical Education), 16(1), 1-7. https:// doi.org/10.1186/s12909-016-0739-5

Belk, C., \& Maier, V. B. (2013). Biology, science for life with physiology, fourth edition, pearson education. The United States of America: Pearson Education.

Budiarto, M. T., Khabibah, S., \& Firdaus, A. M. (2020). Misconception of junior high school students on two-dimentional figure materials. Daya Matematis: Jurnal Inovasi Pendidikan Matematika, 8(1), 1-8. https://doi.org/10.26858/jds.v8i1.13316

Çimer, A. (2012). What makes biology learning difficult and effective: Students' views. Educational Research and Reviews, 7(3), 61-71. https://doi.org/10.5897/ERR11.205

Duda, H. J., Wahyuni, F. R. E., \& Setyawan, A. E. (2020). Misconception of the biology education students on the concepts of fermentation. Journal of Physics: Conference Series, 1521(4), 1-8. https://doi.org/10.1088/1742-6596/1521/4/042006

Duda, H. J., Wahyuni, F. R. E., \& Setyawan, A. E. (2020). Student misconseption analysis in the biotechnology concept with certainty of response index. International Journal of Education Humanities and Social Science, 3(1), 111-121.

Etobro, A. B., \& Fabinu, O. E. (2017). Students' perceptions of difficult concepts in biology in senior secondary schools in Lagos state. Global Journal of Educational Research, 16(2), 139_ 147. http://dx.doi.org/10.4314/gjedr.v16i2.8 GLOBAL

Fauzi, A., \& Fariantika, A. (2018). Courses perceived difficult by undergraduate students majoring in biology. Biosfer, 11(2), 78-89. https://doi.org/10.21009/biosferjpb.v11n2.78-89

Firdaus, N. R., Kirana, T., \& Susantini, E. (2021). A four-tier test to identify students' conceptions in inheritance concepts. IJORER: International Journal of Recent Educational Research, 2(4), 402-415. https:// doi.org/10.46245/ijorer.v2i4.128

Gunstream, S. E. (2012). Explorations in basic biology, twelfth edition. San Francisco, California: Pearson Benjamin Cummings.

Gurel, D. K., Eryilmaz, A., \& McDermott, L. C. (2015). A review and comparison of diagnostic instruments to identify students' misconceptions in science. Eurasia Journal of Mathematics, Science and Technology Education, 11(5), 989-1008. https://doi.org/10.12973/eurasia.2015.1369a

Halim, A. S., Finkenstaedt-Quinn, S. A., Olsen, L. J., Gere, A. R., \& Shultz, G. V. (2018). Identifying and remediating student misconceptions in introductory biology via writingto-learn assignments and peer review. CBE Life Sciences Education, 17(2), 1-12. https://doi.org/10.1187/cbe.17-10-0212

Halim, L., Yong, T. K., \& Meerah, T. S. M. (2014). Overcoming students' misconceptions on forces in equilibrium: An action research study. Creative Education, 5(11), 1032-1042. 
Analysis of Students' Misconception on General Biology Concepts Using Four-Tier Diagnostic Test (FTDT)

https://doi.org/10.4236/ce.2014.511117

Ichsan, I. Z., \& Mulyani, S. W. W. (2018). Improving students' motoric skills through demonstration method in recycling plastic waste. Jurnal Pendidikan Biologi Indonesia, 4(2), 189-194. https:// doi.org/10.22219/jpbi.v4i2.5890

Istiyani, R., Muchyidin, A., \& Rahardjo, H. (2018). Analisis miskonsepsi siswa pada konsep geometri menggunakan three-tier diagnostic test. Cakrawala Pendidikan, 37(2), 223-236. https:// doi.org/10.21831/cp.v37i2.14493

Ita. (2020). Hasil belajar dan respon mahasiswa terhadap pelaksanaan pembelajaran daring pada mata kuliah biologi umum. Prosiding konferensi Nasional Pendidikan, 2021(1), 143-147.

Jauhariyah, M. N. R., Suprapto, N., Suliyanah, Admoko, S., Setyarsih, W., Harizah, Z., \& Zulfa, I. (2018). The students' misconceptions profile on chapter gas kinetic theory. Journal of Physics: Conference Series, 997(1), 1-14. https://doi.org/10.1088/1742-6596/997/1/012031

Kamilah, D. S., \& Suwarna, I. P. (2019). Pengembangan three-tier test digital untuk mengidentifikasi miskonsepsi pada konsep fluida statis. Edusains, 8(2), 212-220. https://doi.org/10.15408/es.v8i2.5192

Kumandaş, B., Ateskan, A., \& Lane, J. (2018). Misconceptions in biology: A meta-synthesis study of research, 2000-2014. Journal of Biological Education, 53(4), 350-364. https:/ / doi.org/10.1080/00219266.2018.1490798

Kurikulum, T. (2017). Kurikulum prodi pendidikan biologi. Fakultas Pendidikan Ilmu Eksakta dan Keolahragaan, IKIP Budi Utomo Malang.

Laliyo, L. A. R., Hamdi, S., Pikoli, M., Abdullah, R., \& Panigoro, C. (2021). Implementation of four-tier multiple-choice instruments based on the partial credit model in evaluating students' learning progress. European Journal of Educational Research, 10(2), 825-840. https:// doi.org/10.12973/EU-JER.10.2.825

Muliyani, R. (2018). The implementation of refutation text in predict-observe-explain (POE) learning model to decrease students' misconception. Journal of Educational Research and Evaluation, 2(2), 62-71.

Palennari, M., Lodang, H., Faisal, \& Muis, A. (2016). Biologi dasar: Bagian pertama. Alauddin University Press.

Rajhans, V., Memon, U., Patil, V., \& Goyal, A. (2020). Impact of covid-19 on academic activities and way forward in Indian optometry. Journal of Optometry, 13(4), 216-226. https://doi.org/10.1016/j.optom.2020.06.002

Raven, P. H., Johnson, G. B., Mason, K. A., Losos, J. B., \& Singer, S. R. (2017). Biology, eleventh edition. New York, United States: McGraw-Hill Education.

Rukmana, D. (2017). Identifikasi miskonsepsi pada materi prinsip archimedes di smk dengan menggunakan tes diagnostik pilihan ganda tiga tingkat. WaPFi (Wahana Pendidikan Fisika), 2(2), 36. https:// doi.org/10.17509/wapfi.v2i2.8276

Savira, I., Wardani, S., Harjito, \& Noorhayati, A. (2019). Desain instrumen tes three tiers multiple choice untuk analisis miskonsepsi siswa terkait larutan penyangga. Jurnal Inovasi Pendidikan Kimia, 13(1), 2277-2286.

Simon, E., Reece, J., \& Dickey, J. (2013). Campbell essential biology with physiology, pearson education. The United States of America: Pearson Education.

Soeharto, Csapó, B., Sarimanah, E., Dewi, F. I., \& Sabri, T. (2019). A review of students' common misconceptions in science and their diagnostic assessment tools. Jurnal Pendidikan IPA Indonesia, 8(2), 247-266. https://doi.org/10.15294/jpii.v8i2.18649

Syamsiar, A. A., \& Raharjo. (2021). Profile of misconseption on genetic substance topic on student grade xii with four-tier diagnostic test. BioEdu (Berkala Imiah Pendidikan Biologi), 10(3), 523-529.

Syarafina, Mustofa, Z., \& Prayitno, T. A. (2020). Penerapan soal four tier untuk mengidentifikasi miskonsepsi siswa pada materi aktivitas jantung dan pembuluh darah. Biosfer: Jurnal Biologi dan Pendidikan Biologi, 5(1), 6-13. http://dx.doi.org/10.23969/biosfer.v5i1.2406

Tahya, N. P. D., \& Kayadoe, V. (2020). Students misconseption indentification of chemical 
candidates teachers using three tier test method in the basic concept of chemical bond. Edu Sciences Journal, 1(1), 37-43. https://doi.org/10.30598/edusciencesvol1iss1pp37-43

Üce, M., \& Ceyhan, İ. (2019). Misconception in chemistry education and practices to eliminate them: Literature analysis. Journal of Education and Training Studies, 7(3), 202. https:// doi.org/10.11114/jets.v7i3.3990

Verkade, H., Mulhern, T. D., Lodge, J., Elliott, K., Cropper, S., Rubinstein, B., Horton, A., Elliott, C., Espinosa, A., Dooley, L., Frankland, S., Mulder, R. \& Livett, M. (2017). Misconceptions as a trigger for enhancing student learning in higher education. The University of Melbourne.

Wahyono, P., \& Susetyorini, E. (2021). Misconceptions of biology education students in Biochemistry course during the covid-19 pandemic. JPBI (Jurnal Pendidikan Biologi Indonesia), 7(2), 104-110. https://doi.org/10.22219/jpbi.v7i2.17093

Waluyo, E. M., Muchyidin, A., \& Kusmanto, H. (2019). Analysis of students misconception in completing mathematical questions using certainty of response index (CRI). Tadris: Jurnal Keguruan dan Ilmu Tarbiyah, 4(1), 27-39. https:/ / doi.org/10.24042/tadris.v4i1.2988

Widarti, H. R., Permanasari, A., \& Mulyani, S. (2017). Undergraduate students' misconception on acid-base and argentometric titrations: A challenge to implement multiple representation learning model with cognitive dissonance strategy. International Journal of Education, 9(2), 105-112. https://doi.org/10.17509/ije.v9i2.5464

Widodo, R. P. A., Lisdiana, \& Nuswowati, M. (2019). Development of teaching materials based on discovery learning on science lessons with adictive and psychotropic themes in middle school. Journal of Innovative, 8(3), 349-357. https:/ / doi.org/10.15294/JISE.V8I1.31079

\footnotetext{
*Trio Ageng Prayitno, S.Pd., M.Pd. (Corresponding Author)

Department of Biology Education, IKIP Budi Utomo, Malang, Indonesia

Jl. Simpang Arjuno No.14B, Kauman, Kec. Klojen, Kota Malang, Jawa Timur 65119, Indonesia

Email: trioageng@gmail.com
}

Nuril Hidayati, S.Pd., M.Pd.

Department of Biology Education, IKIP Budi Utomo, Malang, Indonesia

Jl. Citandui No. 46, Blimbing, Kota Malang, Jawa Timur 65122, Indonesia

Email: hidayatinuril20@gmail.com 